\title{
THE NEW (2017) GREEK CHILD HEALTH BOOKLET
}

\author{
Antoniadou $\mathrm{I}^{1}$, Karalexi M², Attilakos A $\mathrm{A}^{2}$, Xekalaki A ${ }^{1}$, Prasouli A ${ }^{1}$, Lytras $\mathrm{T}^{3}$, \\ Papadimitropoulou $\mathrm{A}^{1}$, Panagiotopoulos $\mathrm{T}^{3}$
}

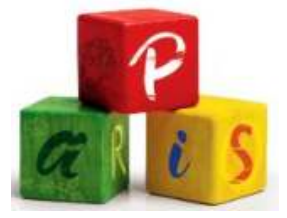

${ }^{1}$ Department of Social and Developmental Paediatrics, Institute of Child Health, Athens, Greece

${ }^{2}$ Third Department of Pediatrics, National \& Kapodistrian University of Athens, "Attikon" Hospital, Athens, Greece

${ }^{3}$ Department of Child Health, National School of Public Health, Athens, Greece

\section{Background}

Primary health care is an important part of health care and provides valuable opportunities for prevention and health education. Our aim was to compose a new version of the Child Health Booklet (CHB), a parent-held health record well-established in Greece, focusing on regular follow-up of children's health and development, health education and support of parents in raising their children.

\section{Methods / Results}

\section{- Guidelines for primary care practitioners based on:}

extensive review of the literature, practices in selected other countries and expert groups of pediatric health care professionals.

- For screening recommendations: grading system adopted by the American Academy of Pediatrics (2004).

\section{- Fifteen specific ages were recommended for scheduled} visits: six in infancy (1-2 weeks, 2, 4, 6, 9 and 12-15 months), four in toddler and pre-school age (18 months, 2$2.5,4$ and 5-6 years), two in school age (7-8 and 9 years), and three in adolescence (11-12, 14-15 and 17-18 years). In each age, essential elements of physical examination

\section{and developmental/behavioral monitoring and}

anticipatory guidance were proposed.

\section{- WHO Child growth standards and WHO References} growth charts were adopted.
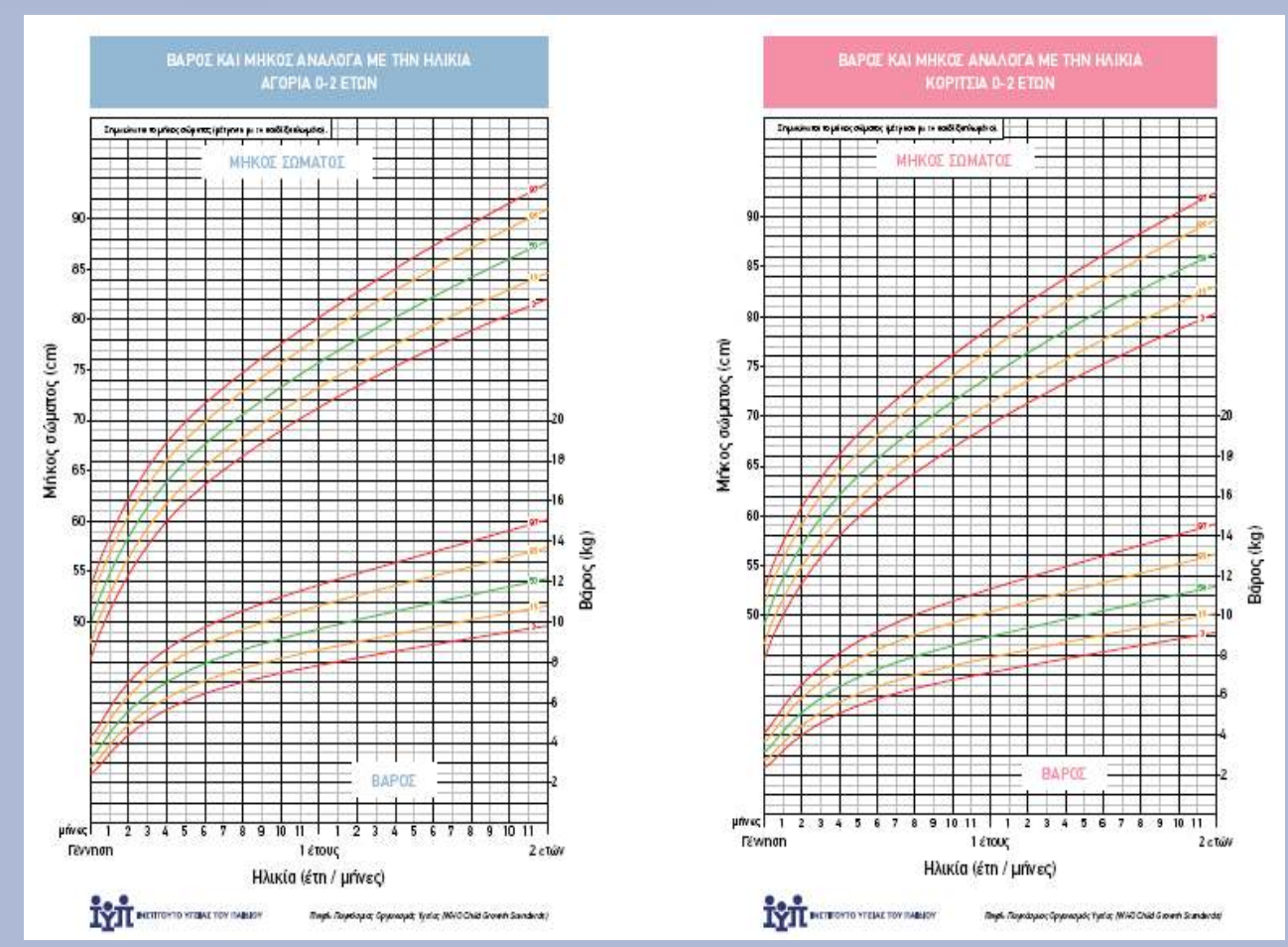

1. American Academy of Pediatrics. Classifying recommendations for clinical practical guidelines. Pediatrics. 200 2. Isaac et al. Quality of reporting and evidence in American Academy of Pediatrics guidelines. Pediatrics. 2013 3. De Onis et al. Worldwide implementation of the WHO Child Growth Standards. Public Health Nutrition. 2012
- The following recommendations for comprehensive or selective screening about hearing, vision, congenital heart defects in newborns, developmental dysplasia of the hip, iron deficiency anemia, dyslipidemia, chlamydia infections \& risk for sudden death in young athletes were made:

\begin{tabular}{|c|c|c|c|}
\hline Disease & Age & $\begin{array}{l}\text { Method of screening/ } \\
\text { Population }\end{array}$ & $\begin{array}{l}\text { Level of } \\
\text { evidence }\end{array}$ \\
\hline \multicolumn{4}{|c|}{ Recommendations for comprehensive screening } \\
\hline $\begin{array}{l}\text { Congenital } \\
\text { heart defects }\end{array}$ & Neonatal & Pulse oximetry & B-1 \\
\hline Hearing loss & Neonatal & $\begin{array}{l}\text { Auditory brainstem response } \\
\text { (ABR) and otoacoustic } \\
\text { emissions (OAE) tests }\end{array}$ & B-2 \\
\hline Vision diseases & $3.5-5$ years & Clinically-Optotype & B-1 \\
\hline \multicolumn{4}{|c|}{ Recommendations for selective screening } \\
\hline $\begin{array}{l}\text { Developmental } \\
\text { dysplasia of the } \\
\text { hip }\end{array}$ & Neonatal & $\begin{array}{l}\text { U/S of the hips } \\
\text { Infants that were born with breech } \\
\text { presentation or have positive family } \\
\text { history in } 1^{\text {st }} \text { or } 2^{\text {nd }} \text { degree relatives } \\
\text { (especially for girls) }\end{array}$ & B-3 \\
\hline $\begin{array}{l}\text { Iron deficiency } \\
\text { anemia }\end{array}$ & $\begin{array}{l}\text { Childhood / } \\
\text { adolescence }\end{array}$ & $\begin{array}{l}\mathrm{Hb}-\text { Ferritin } \\
\text { Infants/children/adolescents at high risk }\end{array}$ & C-3 \\
\hline Dyslipidemia & $>2$ years & 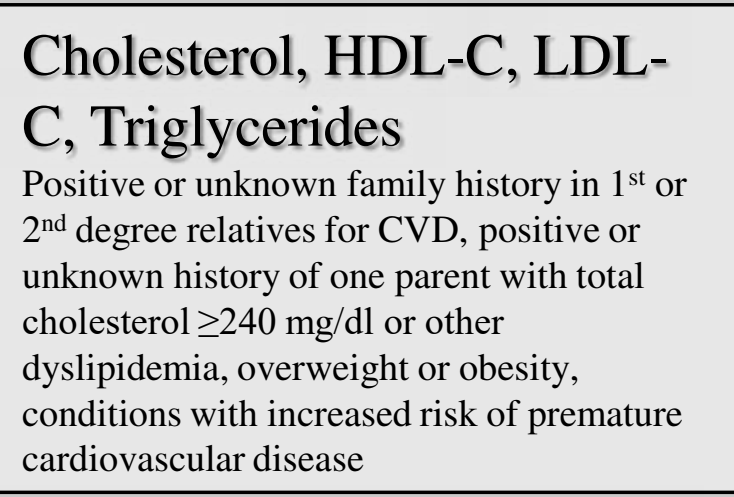 & B-3 \\
\hline $\begin{array}{l}\text { Chlamydia } \\
\text { infections }\end{array}$ & Adolescence & $\begin{array}{l}\text { NAATs in urine / vaginal / } \\
\text { cervical swab } \\
\text { Sexually active adolescents, history of } \\
\text { chlamydia infection or other sexually } \\
\text { transmitted infection, partner with } \\
\text { chlamydia infection or history of } \\
\text { sexual contact without constant } \\
\text { condom use }\end{array}$ & B-3 \\
\hline $\begin{array}{l}\text { Risk for sudden } \\
\text { death in young } \\
\text { athletes }\end{array}$ & $\geq 12$ years & $\begin{array}{l}\text { History-Physical } \\
\text { examination- ECG }\end{array}$ & $\mathrm{C}-2$ \\
\hline
\end{tabular}

